\title{
The impact of housing consumption value on the spatial distribution of welfare
}

\author{
Paul Kilgarriff ${ }^{\mathrm{a}, \mathrm{b}, *}$, Martin Charlton ${ }^{\mathrm{a}}$, Ronan Foley ${ }^{\mathrm{c}}$, Cathal O'Donoghue ${ }^{\mathrm{d}}$

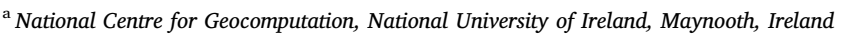 \\ ${ }^{\mathrm{b}}$ Luxembourg Institute of Socio-Economic Research (LISER), Luxembourg \\ ${ }^{\mathrm{c}}$ Department of Geography, Maynooth University, Ireland \\ ${ }^{\mathrm{d}}$ College of Arts, Social Sciences and Celtic Studies, NUI Galway, Ireland
}

A R T I C L E IN F O

\section{Keywords:}

Housing

Data interpolation

Spatial analysis

Inequality

Microsimulation

JEL codes:

C15

C31

D31

D63

R20

R31

\begin{abstract}
A B S T R A C T
The measure of a household's income should include not only monetary components but also non-monetary components and in-kind benefits, such as imputed rent. Imputed rent is the rent an owner can expect to receive were the house on the rental market. This study examined the impact of net imputed rent on the distribution of income in a spatial context. The spatial impact of net imputed rent, mortgage payments, private rent, public rent (social housing schemes) and reverse mortgage/annuity on the spatial distribution of disposable income was examined for the year 2011. A spatial microsimulation model, simulated model of the Irish local economy (SMILE), was used to simulated disposable income at a detailed spatial scale. Rental and property values are estimated at a spatial scale adopting the kriging methodology. The created rental and property data were merged into the SMILE simulated dataset to examine the impact of housing on the spatial distribution of disposable income at a small area level. Results show that the imputed cash flows from property ownership decreases the income share of those at the bottom of the income distribution and is inequality increasing, except in the case of those aged $65+$. Spatially the benefits of housing are greatest in urban areas where property values are highest. The small area measurements of imputed rent highlight the dis-equalising impact imputed rent and housing wealth has on inequality; the rich being able to consume more housing.
\end{abstract}

\section{Introduction}

Consumer durables can provide a stream of benefits to owners (Barr, 1998), which can increase a household's potential to consume (Atkinson, 1983). A comprehensive measure of welfare should include the consumption value derived from consumer durables like housing (Smeeding and Weinberg, 2001). Ireland is used as a case study, to examine the impact of housing costs and benefits on the spatial distribution of income.

A broader definition of household income will include more than employment income but also include non-monetary components and inkind benefits such as imputed rent (Frick and Grabka, 2003; Frick et al., 2007). Two aspects of housing make it interesting, its costs and benefits. The costs are in the form of; rent, mortgage payments or house purchase and benefits; imputed rent and reverse mortgage payments (Nakajima and Telyukova, 2014). Being an owner-occupier does not provide a rental income however, it saves the owner from having to pay market rent (Atkinson, 1983). This should be reflected in total household income.

Net imputed rent consists of gross imputed rent, less any expenditure on maintenance and mortgage interest paid (Frick et al., 2007). For gross imputed rent, the market rent for a similar type dwelling, should be used (UN, 1977). This reflects the hedonic nature of housing (Rosen, 1974). The Canberra Group (UN, 2011) proposed guidelines on how to measure household income and believes in-kind gains such as, property income from net imputed rent should be included. Since 2008, imputed rent and reverse mortgage/annuity values are included in the United Nations system of national accounts

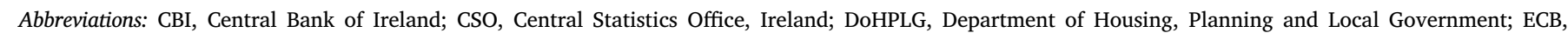

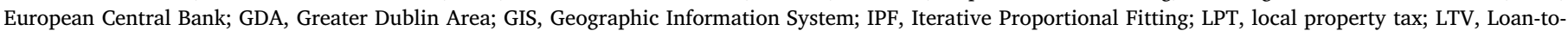

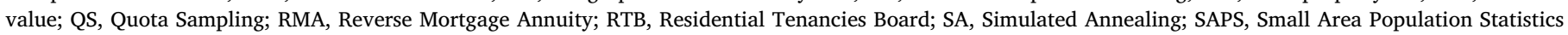

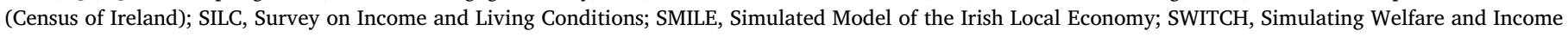
Tax Changes

* Corresponding author.

E-mail address: p.kilgarriff1@gmail.com (P. Kilgarriff).
} 
(UN, 2008), while the Central Statistics Office (CSO), Ireland publish a net imputed rent measure in the national accounts (CSO, 2011) however this is at an aggregated spatial scale.

Previous studies found imputed rent to have an equalising effect on the income distribution (Saunders and Siminski, 2005; Fessler et al., 2016), these studies however, have been restricted to an aspatial scale due to a lack of income data with a spatial component (Balcázar et al., 2014). Aspatial analysis of imputed rent ignores the spatial variation in house prices. If poor people live-in low-cost areas and rich people live in high cost areas, then the distributional effects of adding imputed rent (as an 'income' source) to household income cannot be measured accurately with nationwide imputations as there are large variation between areas.

Regional science offers explanations as to how and why variations in wages and house prices exist across space across space. Thünen (1826) recognised that an interaction exists between space and the economy, the rent for agricultural land rent is a function of yield per unit of land and transport costs. The Alonso (1964), Muth (1969) and Mills (1972) model extended von Thünen's model to an urban environment. This is based on the idea that differences in commuting costs are traded off with differences in the price of living space (Brueckner, 1987). Alonso used bid rent curves to show how households with a given income and set of preferences seek to trade-off the costs and nuisance of commuting, with the advantages of cheaper land with increasing distance to the city centre and the satisfaction of having more living space (Alonso, 1960). The densities, location and prices of urban land are all determined simultaneously. Rich households will have flatter bid rent curves compared to poor households, they also have a higher consumption for housing which attracts them to the suburbs. (Brueckner et al., 1999). At any given location the rich can afford more land and other goods compared to poor households. Poor households are less concerned with the price and quantity of land and more focused on cost and inconvenience of commuting - "Accessibility behaves as an inferior good" (Alonso, 1960).

Regional wage differences can be explained by differences in local amenities (Roback, 1982) and agglomeration economies (Rosenthal and Strange, 2004). The Rosen-Roback specification defines a spatial equilibrium where differences in housing costs account for differences in income and amenities for each individual (Glaeser and Gyourko, 2005). Individuals are trading-off commuting, housing and income simultaneously to maximize their welfare. The spatial pattern of amenities in a city can help to explain why rich income groups live at central locations or in the suburbs. When the level of amenities in the centre are high the rich are more likely to live there (Brueckner et al., 1999). Holding human capital constant, high wages result in higher costs to firms. The spatial equilibrium suggests there is advantages to firms in high wage areas, which offset the costs of conducting business (Glaeser, 2007). Spatial models capture the fact that the residuals produced by hedonic house price equations are often spatially correlated (Balcázar et al., 2017). Despite the availability of detailed house information, previous studies on small area imputed rent have been constrained by a lack of income data at a small area level.

Examining the spatial differences in income and house prices and how they impact on a household's overall level of income is the main objective of this study. A spatial microsimulation approach is used to overcome the lack of income data at a small area level (O'Donoghue et al., 2013a). This dataset is combined with a kriging methodology (Brunsdon and Comber, 2015) to calculate the spatial impact of net imputed rent on the spatial distribution of income.

\subsection{Policy context}

There had been criticism towards the bias that existed in Ireland surrounding owner-occupation (OECD, 2006), particularly the incentivisation of home ownership in rural areas (Gkartzios and Shucksmith, 2015). This resulted in increased calls for the introduction of a property tax (Daly et al., 2009). In an Irish context, the Income Tax Act of 1967 taxed income from the letting of a property or the imputed rent to the owner-occupier. This tax was later abolished in 1969. A domestic rates system had been in place in Ireland since the mid-19th century. These rates were used to fund local government and were based on the valuation of the property. Rates however, were calculated based on the level of funding the local government required for its annual budget. This system was abolished in 1978 (Daly et al., 2009). In 2013, a local property tax (LPT) was introduced (Walsh, 2013). The LPT is a self-assessed tax and it is the responsibility of the owner to select the correct band in which they believe their property belongs to. The LPT website contains some guidance for homeowners; however, the bands are wide with little information given in relation to housing characteristics. This tax can capture some of the in-kind benefits from owner-occupation; however, the tax is on all residential properties including those who rent privately. Callan et al. (2010) recommended an income exemption were a property tax introduced, however the current tax does not discriminate based on income.

When measuring net imputed rent, it is important to consider the underlying structures that exist in a country (Frick and Grabka, 2003; Norris and Winston, 2012). This requires detailed spatial micro data (Meen, 2012). Failure to account for differences in housing systems between two countries (Fahey and Maître, 2004), can lead to invalid conclusions and comparisons (Smeeding and Weinberg, 2001). For example, it is widely acknowledged that mortgage tax relief has minimal impact on ownership percentage (Hendershott and White, 2000), as higher income groups disproportionally capture most of the gains (Matsaganis and Flevotomou, 2007). Such a tax relief is also inequitable towards renters (Bourassa and Grigsby, 2000). In Ireland, which can be defined as having a liberal welfare state regime (Kemeny, 2002), rent prices and imputed rent are expected to be higher compared to countries where the market plays a less important role (Juntto and Reijo, 2010). The Canberra group handbook (UN, 2011) and the OECD Framework (OECD, 2013) has attempted to create a standardised cross-country measure of household income.

\section{Methodology}

\subsection{Income definition}

There are several economic advantages to owner-occupation. The benefit of owner-occupation is twofold, first there is the benefit from not paying private market rent. In many cases, monthly mortgage payments are lower compared to the rent for a similar dwelling (Lyons, 2017a). Secondly, the owned property is a valuable asset which can represent a considerable portion of a household's wealth, Venti and Wise (1991) estimate that housing equity represents as much as $80 \%$ of the wealth of elderly households, many of whom are 'cash-poor and house-rich' (Costa-Font et al., 2010). Owner-occupiers can use the purchase of a property as an investment rather than investing in financial services (Frick and Grabka, 2003). Later in the life-cycle, owner-occupiers benefit from this investment in the form of a reverse mortgage offered by investment firms. A reverse mortgage/annuity (RMA) enables owner-occupiers to use their home as equity to buy an annuity which provide them with regular payments, without the need to move out or sell the house therefore providing security of tenure (Mayer and Simons, 1994). The loan is then repaid with interest, upon the homeowner's death or if they decide to sell. Unlike a mortgage, the homeowner does not make interest or principal payments. The monthly payment received depends upon; the borrower's age and life expectancy, the amount of equity in the home, the expected level of house price appreciation and the interest rate on the loan (Mayer and Simons, 1994). Despite the benefits of RMA in decreasing poverty amongst the elderly (Kutty, 1998; Mayer and Simons, 1994), the demand remains low and the reasons for this are not well understood (Cocco and Lopes, 2014). 
Without including reverse mortgage/annuity in the analysis the household would leave behind a significant amount of equity which is then bequeathed to descendants contributing to inequality (Piketty et al., 2014). Reverse mortgage/annuity payments are included so that the true value of the asset is not underestimated. There are also life-cycle effects, households are at different stages on the life-cycle and will have saved or inherited more wealth than others (Atkinson, 1971; Shorrocks, 1975).

Under the Haig-Simons definition, income is equal to consumption plus change in net worth over the course of the year (Smeeding and Weinberg, 2001). If this annual approach is adopted households at different stages of the life-cycle are being compared to each other. Including both annual and lifetime approach aspects is more intuitive. A number of assumptions are made as you are forecasting over a longer time period (Barthold, 1993). Using reverse mortgage/annuity however treats households as separate units as the household will consume the value of the property before death. Households can overconsume to make up for periods of under consumption, i.e. when paying a mortgage.

Net imputed rent is proven to decrease inequality and reduce poverty especially for the elderly (Törmälehto and Sauli, 2013). Several studies found that by including wealth indicators such as imputed rent, the living standards for the elderly increase (Frick and Headey, 2009; Callan and Keane, 2009; Pellegrino et al., 2011). A tax on imputed rent may not necessarily be progressive, especially in countries where the elderly have lower cash incomes compared to other groups (i.e. cash poor, asset rich) (Figari et al., 2016; Pellegrino et al., 2011; Yates, 1994). Sometimes households are unable to provide their own dwelling and rely on the State to provide housing. Paulus et al., (2010) state this public transfer in-kind would have to be paid out of disposable income, were it not provided publicly by the state. The benefits of imputed rent to social renters are found to be substantial, decreasing poverty rates as much as $10 \%$ (Grabka and Verbist, 2015).

\subsection{SMILE}

This paper adopts a spatial microsimulation approach to overcome the lack of published income data at a detailed spatial scale. Census data typically has a spatial component but no income information, whereas surveys typically have individual incomes but no spatial information. This study utilises the simulated model of the Irish local economy (SMILE), which uses a data fusion process to match micro data using a statistical algorithm with census data, to generate spatial micro data (O'Donoghue et al., 2013a).

The SMILE model uses a Quota Sampling (QS) methodology, developed by Farrell et al. (2010), (2013). QS is less computationally intensive compared to Simulated Annealing (SA) or Iterative Proportional Fitting (IPF) (Farrell et al., 2013; Hynes et al., 2009). QS reweights survey data according to Census quotas for each area. Micro data is first randomly ordered, this data is sampled until the quotas - set by the constraint variables from the census - are filled.

In the SMILE procedure, a limited number of constraint variables are chosen to improve computational efficiency and non-convergence. The constraining variables used in SMILE are gender, education level, age group and household size. These variables were used so that an accurate number of households per district are selected. Regressing the main desired analytical variable, household disposable income, against potential match variables, an $\mathrm{R}^{2}$ value is calculated.

The first stage of the modelling procedure involves filling the quotas for the individual's most at risk of underrepresentation. Demographic characteristics of those households at risk of being underrepresented in the model are identified. This allows for these households to be filled first with all constraints used. A random distribution of households sorted by household size is created. Using this ordering ensures an accurate number of households. This stage ends when no further households can be assigned. The next stage involves the creation of a demographic profile of those quotas unfilled. At this stage quotas have reached $95 \%$ accuracy. A constraint is removed after each iteration until the quotas are filled. The spatial microsimulation procedure is complete when a selection of individuals from the micro dataset can reproduce the SAPS tables with a less than $5 \%$ difference. The output file for each district contains the same number of individuals and households as in the SAPS, this ensures that it can be spatially aggregated and disaggregated by ED, county or province. The remaining variables in the microdata set are merged into the simulated data based on the common individual and household identifier.

\subsection{Validation}

To test the reliability and credibility of the simulated data it is necessary to validate the model. This involves in-sample and out-ofsample validation. The in-sample validation involves comparing the proportion generated using the simulated data with the proportion generated using SAPS data. Such in-sample validation can be used as the variables overlap between the two datasets.

Where data did not previously exist, out-of-sample validation is used. This method of validation involves comparing the synthetic data with new external data. The data in both datasets is aggregated to the same spatial scale. In the case of the SMILE model, at-risk of poverty estimates from Watson (2005) are used. Poverty estimates from SMILE simulated data, are compared with estimates from external data.

One of the major issues with spatial microsimulation is in relation to the non-overlapping variables which are likely to suffer from unexplained spatial heterogeneity. As mentioned earlier the overlapping variables in SMILE are age, sex, education and number of persons per household. Non-overlapping or unconstrained variables include labour market variables such as occupation, employment status in addition to housing variables; have a mortgage, renting etc. An out-of-sample validation of the unconstrained variables against new external data highlighted substantial variability in the correlations amongst the unconstrained variables. A Monte-Carlo Simulation approach is adopted in SMILE to correct some of these issues (O'Donoghue et al., 2013a). It uses nested equations which mainly relate to the labour market. A set of parameters are estimated which relate to the explained part of the equation, an error term is also included. Without the error term the calibration method will only select those with a high probability of having certain characteristics, i.e. based on a combination of characteristics it would go with the most probable. Even after this process there may still be unexplained spatial heterogeneity. The unconstrained variables may have a poor relationship with the constrained variables. To overcome this, the variables simulated during the Monte-Carlo Simulation are calibrated to exogenous constraints. These external totals used in this calibration process are from census small area data. Correlation coefficients are calculated between the SMILE data and the external data for each of the labour market variables. These results are adjusted so they match the external data.

\subsection{Household income}

This process is followed by an alignment procedure whereby market incomes are readjusted to be representative of national accounts. In calibrating income, attention is required as adjustments can have implications on the distribution. A ratio of average income by source to the national average is utilised in the SMILE model to ensure the underlying distribution of incomes remains (Morrissey and O'Donoghue, 2011). The synthetic data is also calibrated to be consistent with county level income data from the CSO national accounts. Absolute values are used so that the distributional characteristics of the survey data are maintained. This calibrating allows for unobserved spatial heterogeneity and ensures the same CSO county ratios are maintained (O'Donoghue et al., 2013b).

A spatial microsimulation methodology has enabled a spatially rich 


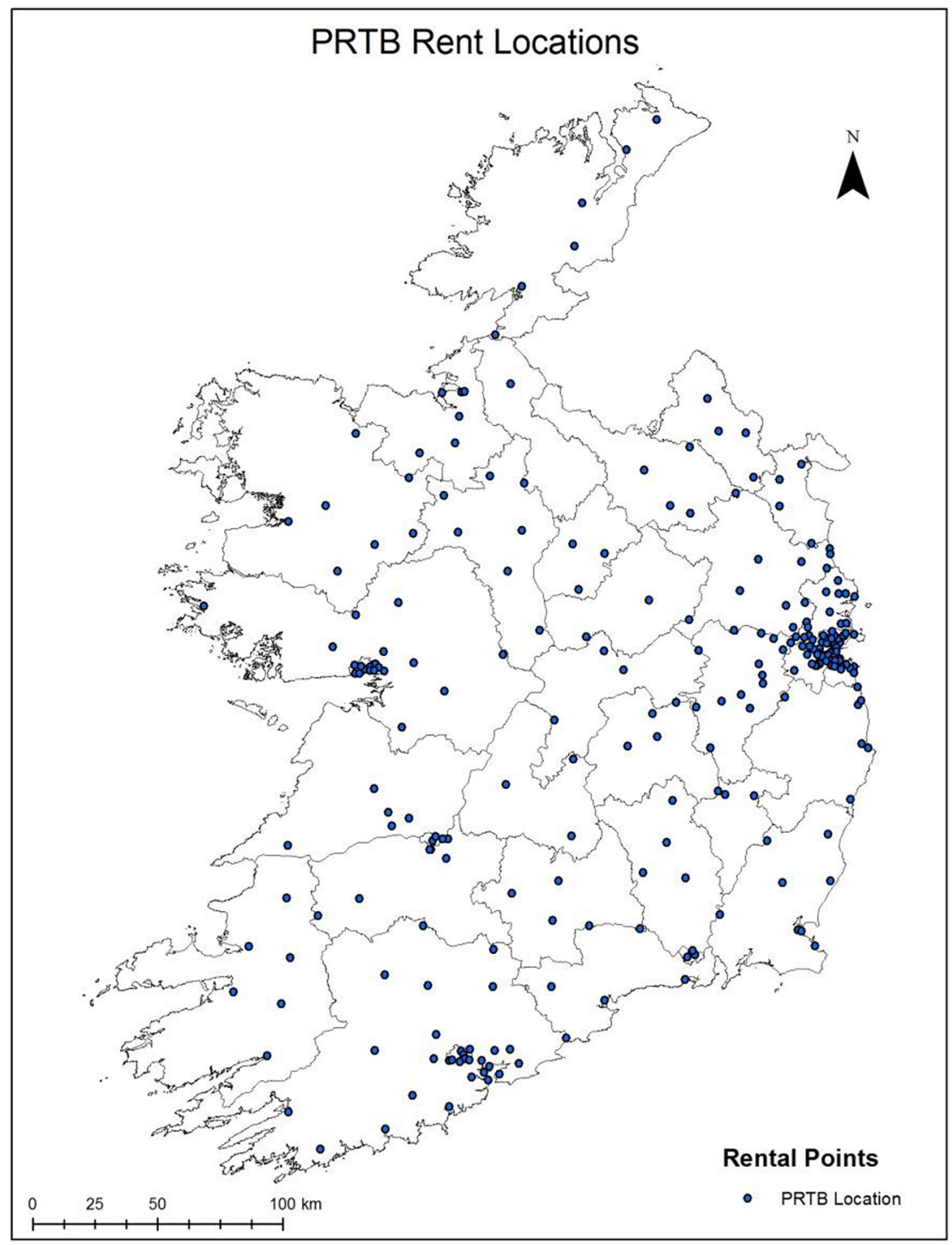

Fig. 1. PRTB Rental locations geocoded.

micro-dataset be created. This dataset contains individual level data on socio-economic and demographic characteristics as well as income measures such as market income, disposable income, taxes paid and social transfers received (Morrissey and O'Donoghue, 2013). The calibration and alignment techniques ensure that the data presented in SMILE is representative. The disposable income measure created consists of income generated from employment, non-work income such as income generated from investments, social benefits and less any taxes.

$Y_{i}=w_{i}+f_{i}+b_{i}-t_{i}$

Where $Y_{i}$ is an individual's total personal income, $w_{i}$ is employment income, $f_{i}$ is non-employment income such as investments, $b_{i}$ are social benefits and $t_{i}$ any taxes (includes tax on employment income, nonemployment income and social benefits). The SMILE model accounts for the complex nature of the tax-benefit system. Income is modelled net of taxes and benefits. A static microsimulation model of the Irish taxbenefit system was developed (O'Donoghue et al., 2013a). In Ireland a number of similar models have been developed such as the SWITCH model (Callan et al., 1996) as part of a European tax-benefit model (O'Donoghue, 1998). A simplified Tax-Benefit microsimulation model was programmed in Stata to model the spatial distribution of income net of taxes and benefits. This model is consistent with other publicly available models such as EUROMOD.

\subsection{Household composition}

Equivalence scales are used to take account of the varying composition of households (Atkinson, 1983). Income is measured using an equivalence scale to take account of the need of the household. Different equivalence scales exist (OECD, 2014) however, the national equivalence scale is used as it is the one widely used by the CSO for Survey on Income Living Conditions (SILC) reports and published data used in the creation of SMILE. This scale gives a weighting of 1 to the first adult in the household and 0.66 to each subsequent adult ( $>14$ years). Children ( $<14$ years) are each assigned a weighting of 0.33 . The equivalised household disposable income is then calculated for each household using the household total weighting (CSO, 2014).

The household disposable income from SMILE is used as the base measure. Various house components are then added to household income; private rent, public rent (social housing), mortgage costs, imputed rent and reverse mortgage/annuity. A cross-sectional examination of the year 2011 is the focus of this study. This is the latest year for which SMILE model income data is available.

\subsection{Property values}

A number of methodologies can be used to estimate imputed rent 


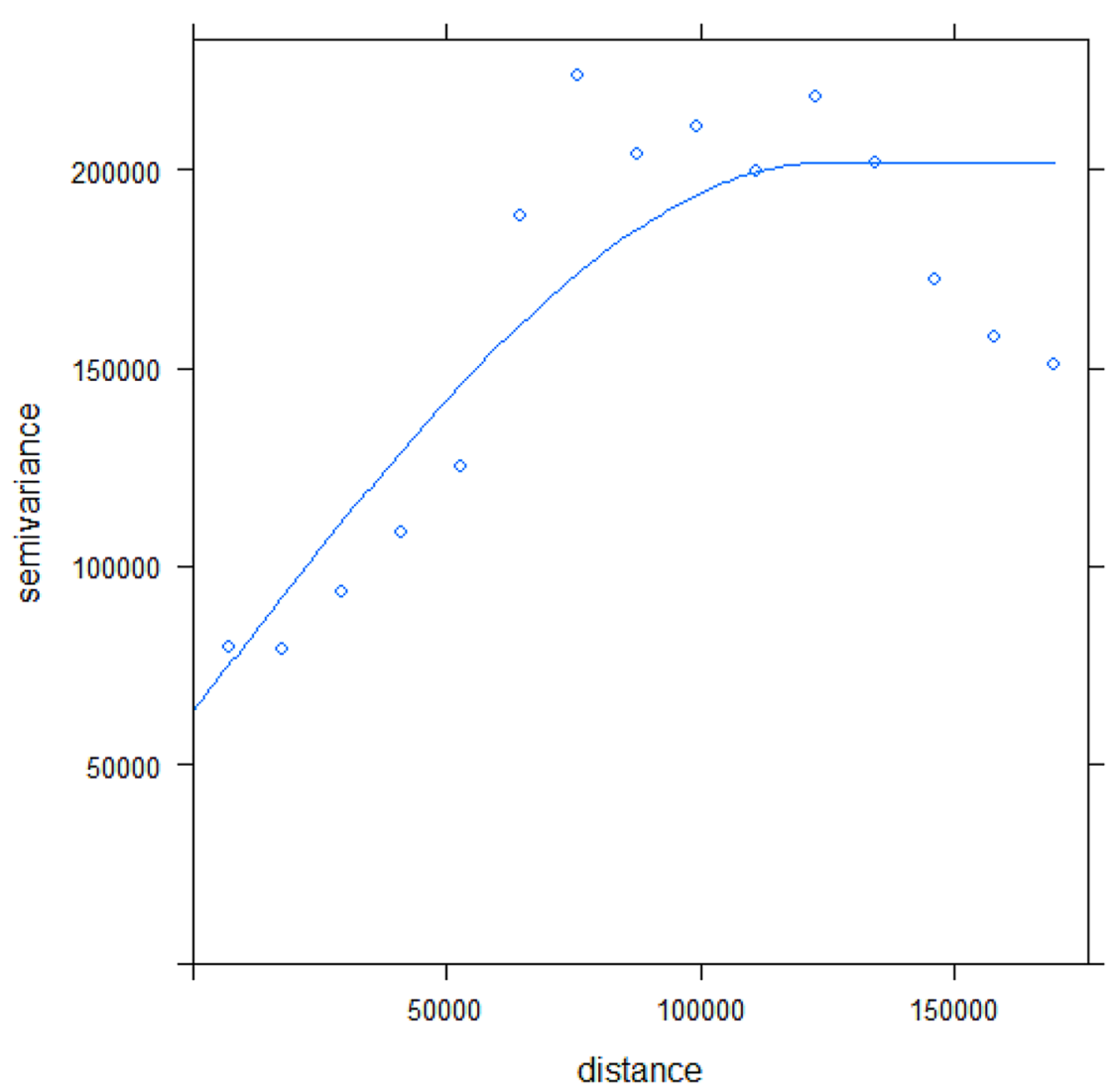

Fig. 2. Estimated variogram from the kriging methodology (distance in metres).

(see Balcazar et al., (2014)). A literature review proved inconclusive in identifying the best method. Spatial models capture the fact that the residuals produced by hedonic house price equations are often spatially correlated (Balcázar et al., 2017). Despite the availability of detailed house information, previous studies have been constrained by a lack of income data at a spatial scale. Using a spatial microsimulation approach has overcome this problem. Using a kriging methodology, house and rental prices at a detailed spatial scale are estimated. The kriging methodology is used to interpolate or smooth the spatial data (Diggle et al., 1998). Kriging operates on best linear unbiased prediction (BLUP) (Goldberger, 1962) and accounts for spatially correlated data. Kriging provides better estimates over other interpolation methods; nearest neighbour interpolation, inverse distance weighting, pycnophylactic interpolation (Anselin and Lozano-Gracia, 2008).

Kriging assumes the variance-covariance matrix can be estimated as a function of distance only. When applied, kriging creates a smooth interpolation surface between data points. The variance-covariance matrix is estimated by computing a variogram (Pace et al., 1998). The pair-wise squared differences among all errors, are plotted against the distance between the pair points (Bailey and Gatrell, 1995). There is a boundary where the distance is greatest and at which the value of one point is related to the value of another point (Hoshino and Kuriyama, 2010). As distance increases the covariance converges towards zero. The points beyond this range will have zero impact on the points inside the range or boundary. In kriging a greater weight is given to points which are closer in distance to the dependant (Dubin et al., 1999) following Tobler's Law (Tobler, 1970). Kriging is often used to estimate real estate values (Hoshino and Kuriyama, 2010; Pace et al., 1998; Dubin et al., 1999, 1992; Basu and Thibodeau, 1998; Montero and Larraz, 2010).

The rental data used is from the Residential Tenancies Board (RTB) (PRTB, 2011) rental index. Under the Residential Tenancies Act (2004) landlords are legally obligated to register with the RTB. The dataset compiled by the ESRI, began in 2007 and is based upon the RTB's register (which contains 284,038 registered landlord properties) of tenancies. The database is the largest rental index in Ireland and is populated with information on actual/agreed rent (assuming all landlords are compliant), location, ${ }^{1}$ six categories of dwelling types, accommodation size and number of occupants and tenancy length.

For the year 2011 the published RTB data contains 393 rental data locations, with a higher frequency of points in urban areas. Each location represents the average rent received in a catchment area and contains data broken down by property type and number of bedrooms. This rental location data was geocoded using An Post's Geodirectory database. The address points contained only limited address string data. These data were geocoded manually based on the location detail provided, typically a town or parish name. Using ArcGIS software all properties in the Geodirectory were plotted. A search was performed using each address to highlight each Geodirectory property where there was a match. The weighted centre point of a cluster of addresses was chosen. In towns and villages, the address 'main street', 'church street' or 'square' was selected as this represents the centre point of the area.

The rental points are plotted in the software programme ' $R$ '. Using the kriging methodology the variogram (Fig. 1) is estimated. The variogram is fitted to the data to determine the range, sill and nugget [Fig. 2]. Beyond a distance of $76.3 \mathrm{~km}$ rental points no longer have an effect on the interpolated value. A rental value for each of the 3,409 EDs is estimated using the centroid point of the polygon. The output from kriging is an estimation of private rent for an area, broken down by property type and number of bedrooms.

These estimated values are used in the model to represent both private rental and imputed rent prices. Social housing rents are calculated using rent supplement values from the Department of Social

\footnotetext{
${ }^{1}$ Data is aggregated and reported at an unusual parish/barony hybrid administrative boundary scale.
} 


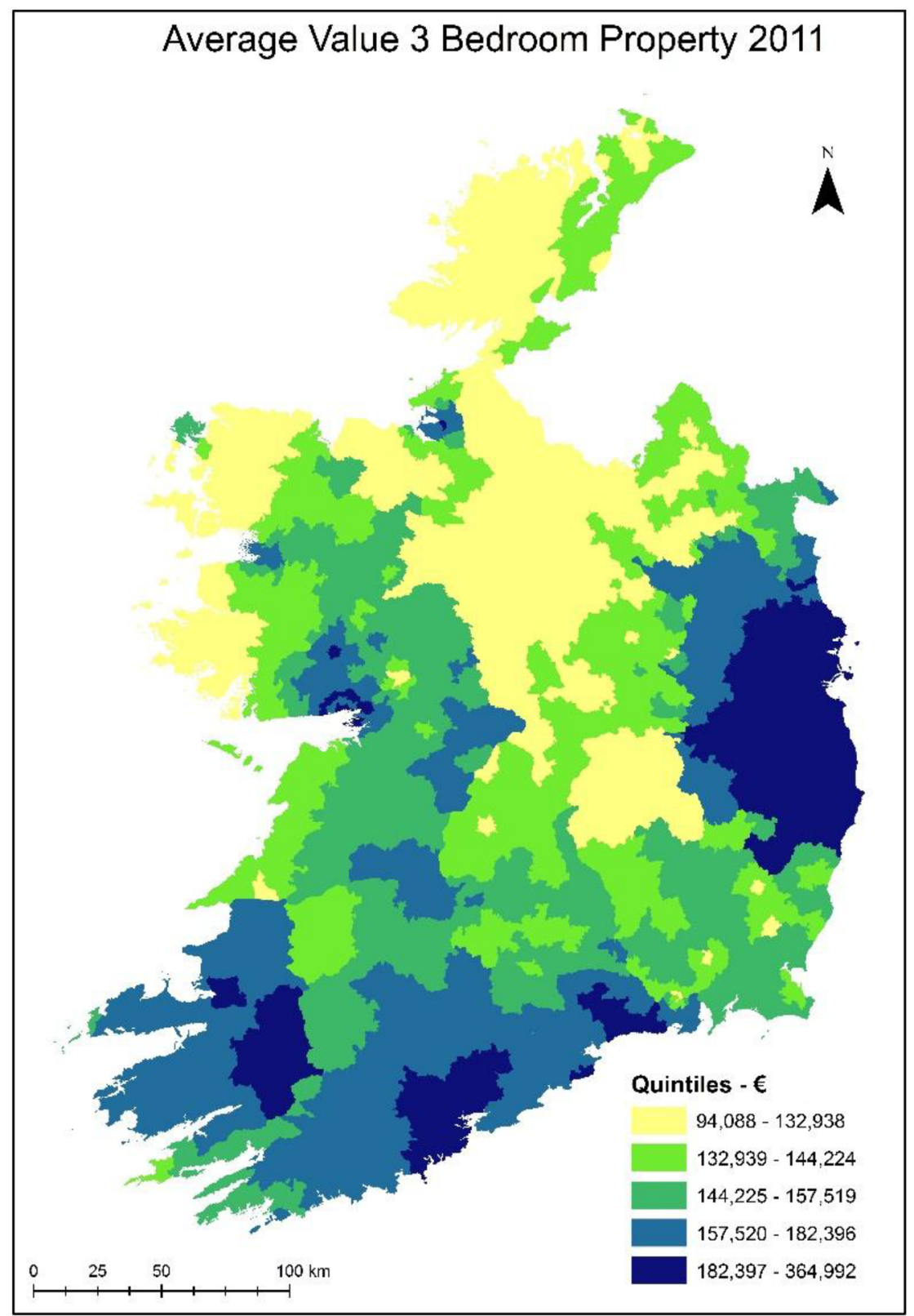

Fig. 3. Average price of 3 bedroom property at ED level in 2011.

Table 1

Variable definitions.

\begin{tabular}{ll}
\hline Variable & Definition \\
\hline Disposable income & Equivalised household disposable income \\
Housing costs & $\begin{array}{l}\text { Private rent costs + social housing costs }+ \\
\text { mortgage costs }\end{array}$ \\
Imputed rent & Imputed rent household receives \\
Net imputed rent & Imputed rent-Housing costs \\
Reverse mortgage/annuity & Must own house outright (no mortgage) \\
Net housing & Imputed Rent-Housing costs + reverse mortgage/ \\
& annuity (RMA) \\
\hline
\end{tabular}

Protection (DSP, 2011). The maximum band value for the area is used. The estimated private rental value is subtracted from the band value to calculate the imputed rent benefit to those in social housing.

Mortgage repayment costs are estimated using average house prices over time. The Department of Housing, Planning and Local Government (DOHPLG) gather average house price data based on mortgage approval data (Department of Housing, 2016). Although the data has information on actual house sales, it lacks spatial detail. Values are broken down by year (1971-2016) and by several categories; national, Dublin, Cork, Galway, Limerick, Waterford and other areas. The averages for new houses which represents a three-bedroom semi-detached house is used (DoHPLG, 2017). Data from the property website Daft.ie are used to disaggregate at a detailed spatial scale (35 units) and break down prices by number of bedrooms (Lyons, 2011). Property prices are then modelled based on the relationship between the threebedroom property in the Daft data and the Dept. of Housing Data.

$$
\operatorname{Prop}_{c i t}=\left[\frac{\text { Rent }_{\text {cit }}}{\text { Med_Rent }_{c i t}}\right] *\left\{\operatorname{Dept}_{c t} *\left[1+\frac{\text { Daft }_{c i t}-\text { Daft }_{c 3 t}}{\text { Daft }_{c 3 t}}\right] *\left[\frac{\text { Daft }_{c 3 t}}{\text { Dept }_{c 3 t}}\right]\right\}
$$

Where $c$ is location, $i$ is number of bedrooms and $t$ is the year. Prop is the value of the property, Rent is the ED rental value, Med_Rent is the median county rental value, Department is the DOHPLG property value and Daft is the Daft.ie property list price. Taking this approach account for differences in house prices between EDs. 
Table 2

Household median income by age group of households (using age of head of household).

\begin{tabular}{|c|c|c|c|c|c|c|}
\hline Age group & $\begin{array}{l}\text { Median employment } \\
\text { income }\end{array}$ & $\begin{array}{l}\text { Median equivalised } \\
\text { disposable income }\end{array}$ & $\begin{array}{l}\text { Median net } \\
\text { imputed rent }\end{array}$ & $\begin{array}{l}\text { Median reverse mortgage/ } \\
\text { annuity payment }\end{array}$ & $\begin{array}{l}\text { Median equivalised income } \\
\text { (including housing) }\end{array}$ & $\%$ Non-homeowners \\
\hline $15-35$ & $€ 13,359$ & $€ 20,165$ & $€ 0$ & $€ 0$ & $€ 22,126$ & $69.0 \%$ \\
\hline $36-50$ & $€ 21,178$ & $€ 19,978$ & $€ 1,359$ & $€ 3,006$ & $€ 25,459$ & $29.1 \%$ \\
\hline $51-65$ & $€ 16,266$ & $€ 19,124$ & $€ 5,066$ & $€ 5,846$ & $€ 30,590$ & $14.2 \%$ \\
\hline $65+$ & $€ 13,942$ & $€ 16,612$ & $€ 5,103$ & $€ 12,060$ & $€ 38,118$ & $4.3 \%$ \\
\hline $15-65$ & $€ 16,314$ & $€ 19,686$ & $€ 1,929$ & $€ 2,485$ & $€ 26,004$ & $39.0 \%$ \\
\hline
\end{tabular}

Table 3

Share of housing tenure by age group.

\begin{tabular}{lllll}
\hline Age group & Has mortgage & $\begin{array}{l}\text { Private } \\
\text { renting }\end{array}$ & $\begin{array}{l}\text { Social } \\
\text { housing }\end{array}$ & $\begin{array}{l}\text { Owner occupied } \\
\text { (without a mortgage) }\end{array}$ \\
\hline $15-35$ & $27.4 \%$ & $59.6 \%$ & $10.1 \%$ & $2.8 \%$ \\
$36-50$ & $41.8 \%$ & $11.2 \%$ & $21.6 \%$ & $25.4 \%$ \\
$51-65$ & $0.8 \%$ & $2.0 \%$ & $10.4 \%$ & $86.8 \%$ \\
$65+$ & $0.0 \%$ & $0.4 \%$ & $1.7 \%$ & $97.9 \%$ \\
$15-65$ & $22.9 \%$ & $24.2 \%$ & $13.9 \%$ & $39.0 \%$ \\
\hline
\end{tabular}

The Department of Housing gather average house price data based on mortgage approval data (Department of Housing, 2016). The data is presented is an average for a three-bedroom semi-detached house. Although the data has information on actual house sales, it lacks spatial detail. Values are broken down by year (1971-2016) and by several categories; national, Dublin, Cork, Galway, Limerick, Waterford and other areas. We use the averages for new houses which represents a three-bedroom semi-detached house. In tandem with this dataset data from the Daft.ie (Lyons, 2017b) is used which contains more detailed spatial information. The report contains average house list prices broken down by Local Authority ${ }^{2}$ and number of bedrooms (1-5). Combining both data sources together enables the lack of spatial detail in the Department of Housing data and the lack of actual sales prices in the Daft.ie data to be overcome.

Fig. 3 shows the highest property values are in the south-west around Cork city and East around Dublin city. The price differentials in housing are clearly illustrated in the map across space.

During the spatial microsimulation process mortgage is not used as a matching variable, this results in limited mortgage data at the household level. Data from the Central Bank of Ireland (CBI) shows that 28 is the average age at which people typically draw down a mortgage and $78.7 \%$ is the average loan-to-value (LTV) percentage (RTÉ, 2016). Unfortunately, this data is not available historically. In 2011, the difference in the interest rate across mortgage types (tracker, variable and fixed rate) was minimal. To overcome this issue all mortgages are taken to be variable rate mortgages with the European Central Bank (ECB) variable rate interest rate for 2011 of $1.25 \%$ (ECB, 2016). Using the age of the head of the household in SMILE and a mortgage drawdown age of 28 , the year in which they purchased the house and house price is estimated. A LTV rate of $78.7 \%$ and Prop $_{\text {cit }}$ is used to calculate the value of the mortgage, mortgage repayments and interest on repayments.

Despite RMA typically given to those aged 62 and over (Mayer and Simons, 1994), an age limit is not applied as any owner-occupier has the option of a RMA (Rasmussen et al., 1997). The lender can consider the uncertainty around length-of-life when calculating payments and use an age-dependant discount rate with later years discounted at an increasing rate (Fratantoni, 1999). Using this rate, older age categories will receive higher payments, as these payments are expected over a shorter period.

\footnotetext{
${ }^{2}$ Prices are broken down by Local Authority outside of Dublin. Inside Dublin the Local Authority of Dublin City is split into north and south city. In addition, Tipperary is not broken into its two local authorities of north and south.
}

\subsection{Age group analysis}

Table 1 shows the definitions of the various measures used to estimate the impact of housing on inequality and income. Each measure has been equivalised so a more accurate comparison to equivalised disposable income can be made.

Table 2 shows income and rent measures broken down by age group. The elderly has the lowest income across age groups however, the high levels of imputed rent and annuity compensate for this. After taking account of housing costs and benefits the $65+$ group moves from having the lowest levels of income to having the highest. Due to life-cycle effects younger age categories are less likely to own a property (69\% are non-homeowners) and therefore do not benefit from having reverse mortgage/annuity or imputed rent.

In Table 3 as age increases, the probability that an individual has a mortgage or is private renting decreases. In the $65+$ age category $97.9 \%$ are owner-occupiers and only $0.4 \%$ are renting. The high $\%$ private renting in the 15-35 age category face two main disadvantages; they are not paying into an asset and secondly not receiving the in-kind benefits.

\section{Results}

Quintiles are used to map the data and results. Each quintile contains an equal number of households. Using quintiles is a means to reduce the complexity of the data but still be able to identify trends. Figs. (4) and (5) show the spatial distribution of income before and after housing costs and benefits are included. Fig. 4 shows a concentration of wealth in Dublin City and around the cities of Limerick and Cork. After accounting for housing costs and benefits (Fig. 5), this concentration of wealth in Dublin has spread into the Greater Dublin Area (GDA) (right side map and inset), while it has decreased around Limerick and Cork cities. The increase in wealth in the GDA is largely due to owner-occupiers benefiting from higher rental and property values. These higher property values translate into higher net imputed rent and RMA payments. Table 4 shows that while there is a lower \% of owner-occupiers in Dublin City and County compared to rural areas, the high property values appear to offset the costs inflicted upon those renting. The high net imputed rent and annuity values can hide at an aggregate level, the regressive impact on a particular group.

In Table 5 an examination of the movers (change in quintile) highlights the lifecycle effects. The areas which move down a quintile have higher levels of disposable income, lower levels of imputed rent, younger and well-educated. The areas which move up a quintile tend to be older, less educated, lower employment and have high imputed rent and reverse mortgage/annuity values. This lifecycle impact results in the elderly moving up the income distribution. The elderly benefit from not paying a mortgage or rent and having a positive net imputed rent. Their housing benefits overcome their lack of disposable income and move those in the lower age brackets down a quintile.

Table 6 shows that a lot of the variation in income is occurring within rather than between regions (county level). Housing costs increase inequality from 0.348 to 0.412 nationally. After accounting for housing benefits, overall inequality decreases to 0.320 . Those paying housing costs will not receive these benefits. Housing benefits appear to 


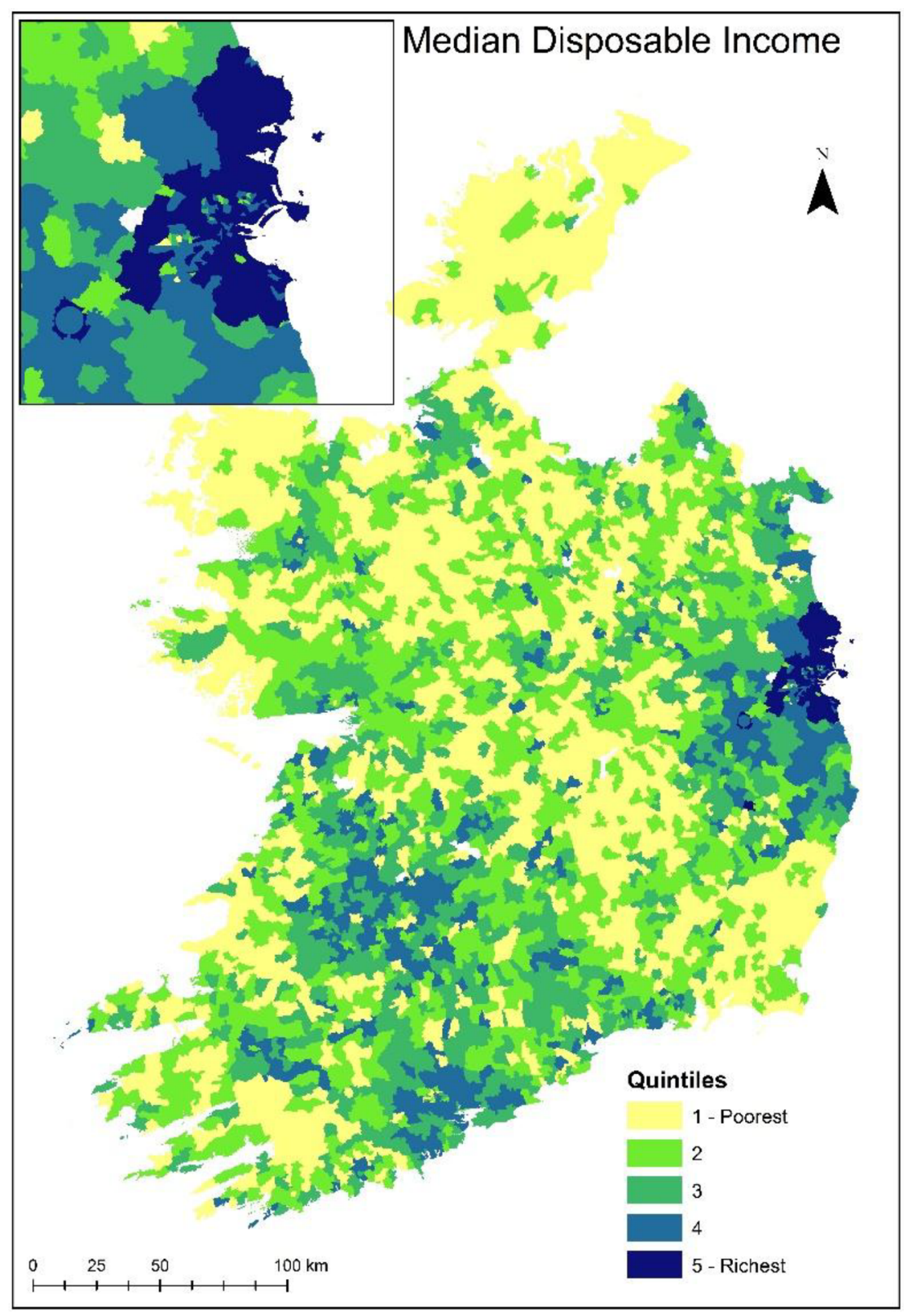

Fig. 4. Quintiles of median equivalised household disposable income (Dublin inset).

cancel out the costs, even if we examine at the small area level. It is important therefore to examine at a household level the impact of housing and the imputed cash flows from property ownership.

One method is to examine the progressivity of the various housing measures. Table 7 reports the Gini Index. The Gini index shows the disequalising impact of imputed rent.

The Lorenz curve in Fig. 6 illustrates this. At the lower end of the income distribution, income net of housing costs and benefits is increasing inequality but as you increase population share the curves cross and it starts to reduce inequality at the upper end of the income distribution.

In Table 8 , the share of income for those in the bottom and top decile decreased from $3.1 \%$ to $1.4 \%$ and $28.5 \%$ to $28 \%$ respectively. The middle deciles have experienced the biggest increase in share of income, with deciles 3-9 all increasing their share. The decrease in income share for the lower deciles is explained by the low levels of home ownership. These groups are disadvantaged from paying housing costs and not receiving same in-kind benefits as owner-occupiers. This raises the issue of the affordability of housing (Kenna et al., 2016). Elderly individuals who were in the bottom quintiles (cash poor but asset rich) have increased their income share after housing costs and benefits are considered. Overall inequality has increased as the gap between the bottom deciles and the middle deciles has widened.

In Fig. 7 Anselin Local Moran's I is utilised to identify clusters and outliers of high/low levels of disposable income after the inclusion of net imputed rent. This method can identify local spatial associations which exist in the data. Examining the z-scores and p-values feature by feature, the measure indicates whether the apparent similarity (spatial clustering of either high or low values) or dissimilarity (a spatial outlier) is more pronounced than you would expect in a random distribution. For example high-high is a statistically significant cluster of high values (ESRI, 2018).

The spatial distribution shows concentrations of high-high $(\mathrm{HH})$ clusters around the GDA in the east of the map and a smaller area around Cork city in the south. There is a line of low-low (LL) clusters running from south-east through the midlands and up towards the north-west.

Utilising the information in Table 9, clusters are described based on their characteristics. 


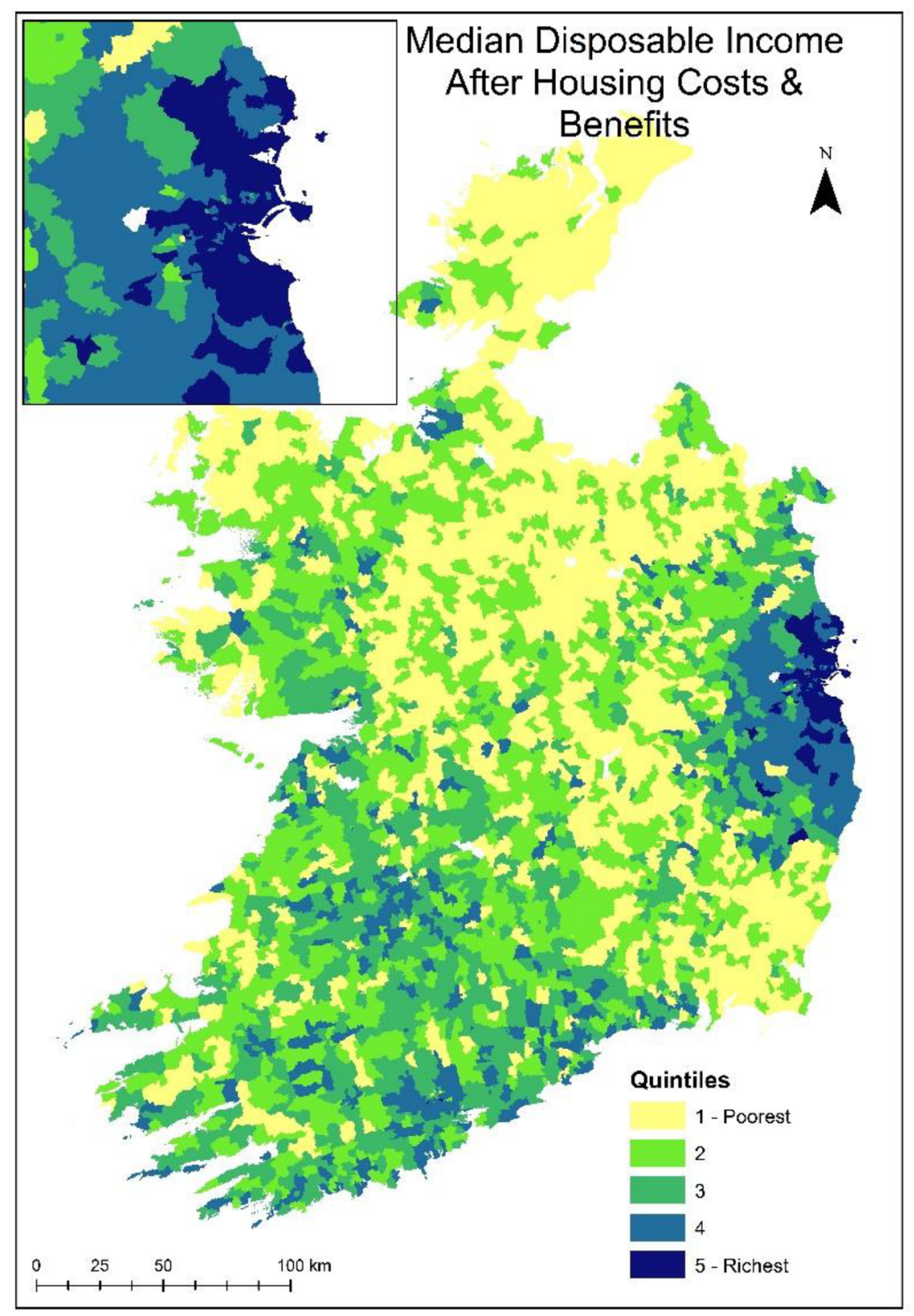

Fig. 5. Quintiles of median equivalised household disposable income including housing costs and benefits (Dublin inset).

Table 4

Housing tenure by urban-rural classification (Population units in households).

\begin{tabular}{|c|c|c|c|c|c|c|}
\hline Location & Population \% & Social housing & Private renting & Owner outright & Has mortgage & Owner occupier \\
\hline Village (200-1499) & $15 \%$ & $13 \%$ & $18 \%$ & $52 \%$ & $18 \%$ & $69 \%$ \\
\hline Town (1500-2999) & $6 \%$ & $10 \%$ & $17 \%$ & $54 \%$ & $19 \%$ & $73 \%$ \\
\hline Town (5000-9999) & $6 \%$ & $11 \%$ & $20 \%$ & $51 \%$ & $18 \%$ & $69 \%$ \\
\hline Town $10,000+$ ) & $17 \%$ & $11 \%$ & $22 \%$ & $49 \%$ & $18 \%$ & $68 \%$ \\
\hline Waterford & $1 \%$ & $11 \%$ & $21 \%$ & $50 \%$ & $18 \%$ & $67 \%$ \\
\hline Dublin county & $12 \%$ & $11 \%$ & $24 \%$ & $45 \%$ & $19 \%$ & $64 \%$ \\
\hline Dublin city & $17 \%$ & $10 \%$ & $19 \%$ & $51 \%$ & $20 \%$ & $70 \%$ \\
\hline
\end{tabular}

LL: Low income, high levels of younger and older people, less educated, more unemployment, sparsely populated. Label: Remote rural areas.
LH: Low income, younger, least educated, highest unemployment, densely populated. Label: inner city areas of poverty and deprivation. HL: Higher incomes, highest owner occupation rates, high levels of 
Table 5

Characteristics of electoral divisions before and after the inclusion of housing costs and benefits and the movers. Up 2 are the EDs that moved up 2 or more quintiles after the inclusion of housing costs and benefits.

\begin{tabular}{lllllll}
\hline & Before & \multicolumn{2}{c}{ After } & & \multicolumn{2}{c}{ Movers (quintiles) } \\
& Q1 & Q5 & Q1 & Q5 & Up 2 & Down 2 \\
\hline $\begin{array}{llllll}\text { Median disposable } \\
\quad \text { income }\end{array}$ & 16,490 & 29,416 & 17,009 & 27,579 & 17,722 & 21,119 \\
Median net housing & 25,090 & 44,190 & 23,778 & 44,046 & 30,363 & 25,183 \\
Mean social rent & 503 & 635 & 517 & 646 & 474 & 499 \\
Mean private rent & 821 & 2,085 & 932 & 1,835 & 839 & 1,581 \\
Mean mortgage costs & 480 & 1,938 & 500 & 1,570 & 565 & 937 \\
Mean imputed rent & 3,796 & 7,902 & 3,425 & 7,970 & 4,995 & 3,535 \\
Mean RMA & 4,922 & 11,252 & 4,059 & 11,865 & 7,220 & 3,264 \\
\% Family & $17.9 \%$ & $10.0 \%$ & $20.2 \%$ & $10.0 \%$ & $14.1 \%$ & $23.1 \%$ \\
\% Owner Occ. & $54.6 \%$ & $51.6 \%$ & $50.3 \%$ & $55.9 \%$ & $60.6 \%$ & $40.1 \%$ \\
Child depend. & $33.7 \%$ & $24.1 \%$ & $35.6 \%$ & $24.8 \%$ & $30.4 \%$ & $38.7 \%$ \\
Old age depend. & $23.3 \%$ & $19.7 \%$ & $20.3 \%$ & $23.6 \%$ & $26.4 \%$ & $11.9 \%$ \\
Tertiary Educ. & $29.2 \%$ & $45.8 \%$ & $30.1 \%$ & $42.9 \%$ & $31.6 \%$ & $38.4 \%$ \\
Employ. rate & $56.4 \%$ & $64.4 \%$ & $56.7 \%$ & $62.5 \%$ & $58.2 \%$ & $62.3 \%$ \\
Unemp. rate & $14.3 \%$ & $8.6 \%$ & $14.4 \%$ & $9.0 \%$ & $12.2 \%$ & $12.6 \%$ \\
Work age Shr. & $63.9 \%$ & $70.3 \%$ & $64.3 \%$ & $68.1 \%$ & $64.1 \%$ & $66.9 \%$ \\
Pop. density & 312 & 4,034 & 201 & 3,708 & 815 & 824 \\
\hline
\end{tabular}

Table 6

Theil I2 index of disposable income + or-the various housing costs and benefits.

\begin{tabular}{llllll}
\hline Variable & I2 & Between & Within & Between \% & Within \% \\
\hline Disposable income & 0.348 & 0.014 & 0.334 & $4 \%$ & $96 \%$ \\
-Costs & 0.412 & 0.012 & 0.400 & $3 \%$ & $97 \%$ \\
$\quad+$ Imputed rent & 0.278 & 0.017 & 0.261 & $6 \%$ & $94 \%$ \\
-Costs + imputed rent & 0.327 & 0.015 & 0.311 & $5 \%$ & $95 \%$ \\
$\begin{array}{l}\text { + Reverse mortgage } \\
\quad \text { annuity }\end{array}$ & 0.301 & 0.020 & 0.281 & $7 \%$ & $93 \%$ \\
+ /-Net costs \& benefits & 0.320 & 0.022 & 0.298 & $7 \%$ & $93 \%$ \\
\hline
\end{tabular}

Table 7

Gini Index of housing measures at the household level.

\begin{tabular}{llll} 
& Disposable Income & Imputed Rent & Net Imputed Rent \\
\hline Gini & 0.37159 & 0.37339 & .38595 \\
\hline
\end{tabular}

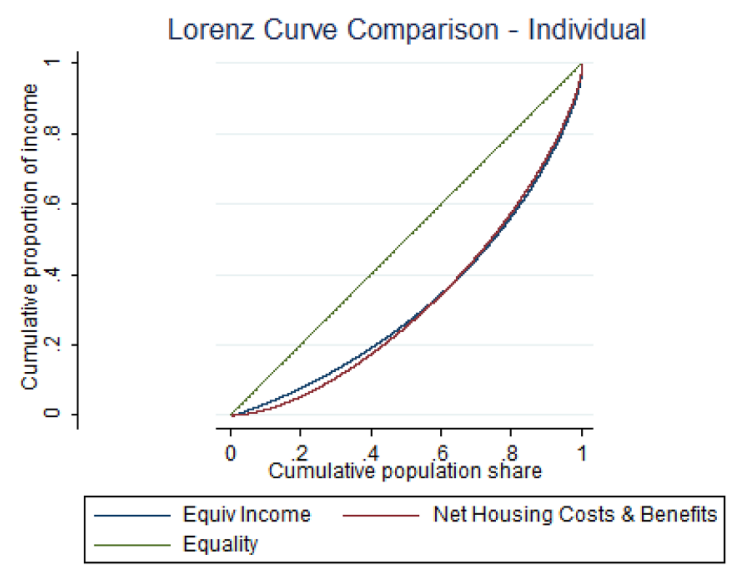

Fig. 6. Population Lorenz curves of equivalised Income Before and After Housing Costs and Benefits.

youth and elderly, middle level of education, lowest unemployment, sparsely populated. Label: Recreational or leisure areas.

HH: Highest incomes, young professionals, highest education levels, high employment rate, densely populated. Label: Middle class city and suburbs.
Table 8

Decile shares of disposable income, minus costs (rent \& mortgage) plus imputed rent and imputed rent plus reverse mortgage/annuity (RMA) payments.

\begin{tabular}{lllllll}
\hline & $\begin{array}{l}\text { Disposable } \\
\text { income }\end{array}$ & $\begin{array}{l}+ \\
\text { Imputed } \\
\text { rent }\end{array}$ & $\begin{array}{l}+ \\
\text { Imputed } \\
\text { RMA }\end{array}$ & $\begin{array}{l}\text { Disposable } \\
\text { income }\end{array}$ & $\begin{array}{l}+ \\
\text { Imputed } \\
\text { rent }\end{array}$ & $\begin{array}{l}+ \\
\text { Imputed } \\
\text { \& RMA }\end{array}$ \\
\hline Decile & $\begin{array}{l}\text { \% of } \\
\text { median }\end{array}$ & $\begin{array}{l}\text { \% of } \\
\text { median }\end{array}$ & $\begin{array}{l}\text { \% of } \\
\text { median }\end{array}$ & Share & Share & Share \\
1 & 48.9 & 29.1 & 29.3 & 3.1 & & \\
2 & 59.4 & 57.6 & 50.4 & 4.1 & 3.0 & 1.4 \\
3 & 69.2 & 74.8 & 69.7 & 4.9 & 5.5 & 3.3 \\
4 & 83.4 & 87.0 & 85.4 & 5.8 & 6.7 & 6.4 \\
5 & 100.0 & 100.0 & 100.0 & 7.0 & 7.7 & 7.7 \\
6 & 121.4 & 115.3 & 117.9 & 8.4 & 8.9 & 9.0 \\
7 & 147.8 & 135.8 & 140.6 & 10.2 & 10.3 & 10.6 \\
8 & 181.9 & 166.6 & 170.3 & 12.5 & 12.4 & 12.8 \\
9 & 235.8 & 216.8 & 222.6 & 15.6 & 15.6 & 15.9 \\
10 & & & & 28.5 & 28.3 & 28.0 \\
\hline
\end{tabular}

A comparison of the two largest clusters HH and LL highlight the urban/rural divide. Those living in urban environments benefit from high employment incomes and higher net imputed rent. However, this is not the case for all urban areas as Galway, Limerick and Waterford cities do not contain any HH clusters. Within the cities of Cork and Dublin the LH cluster has identified pockets of deprivation. This highlights the usefulness of spatial imputed rent as a tool for deprivation analysis.

\section{Conclusion}

Previous studies of imputed rent have been restricted to an aspatial scale due to a lack of income data with a spatial component (Balcázar et al., 2014). Using aggregated measures of imputed rent ignores the variation that exists across space. As rich people consume more property, they will have larger imputed rents, this causes imputed rent to have an overall dis-equalising impact. As this study has shown, this can be illustrated using spatially disaggregated data. Utilising spatial microsimulation (O'Donoghue et al., 2013a) and spatial analysis methods has made it possible to examine imputed rent at a small area level.

The importance of including in-kind benefits in the calculation of disposable income and household welfare is clear. Owner-occupied housing greatly increases a household's potential to consume. After accounting for housing costs in the form of rent and mortgage payments and housing benefits in the form of imputed rent and reverse mortgage/ annuity, the spatial distribution of welfare changes. On average the income share of the GDA increases, however when the movers are examined, the high rents and property values and overall benefits to owner occupiers in the GDA, are masking the high costs young renters face. This highlights the importance of examining issues such as housing inequality at a detailed spatial scale as opposed to aggregate totals. However, overall the net gain to owner-occupiers does not exceed the net loss to non-owner-occupiers and inequality nationally increases. The inequality measures show that overall housing costs and benefits are having a regressive impact on the income distribution with those at the lower end of the income distribution disproportionately affected. The income share of lower groups decreases after net imputed rent.

Inequality however, is not increasing for all age groups and there are clear benefits for older age categories. Reverse mortgage/annuity has the potential to financially protect households $65+$ by acting as an additional pension they have paid into over the term of the mortgage (Moscarola et al., 2015). Using a reverse mortgage/annuity the asset is drawn down until death. Like previous studies, the stream of consumption value provided by housing, compensates the elderly who are 'cash poor but asset rich'. 


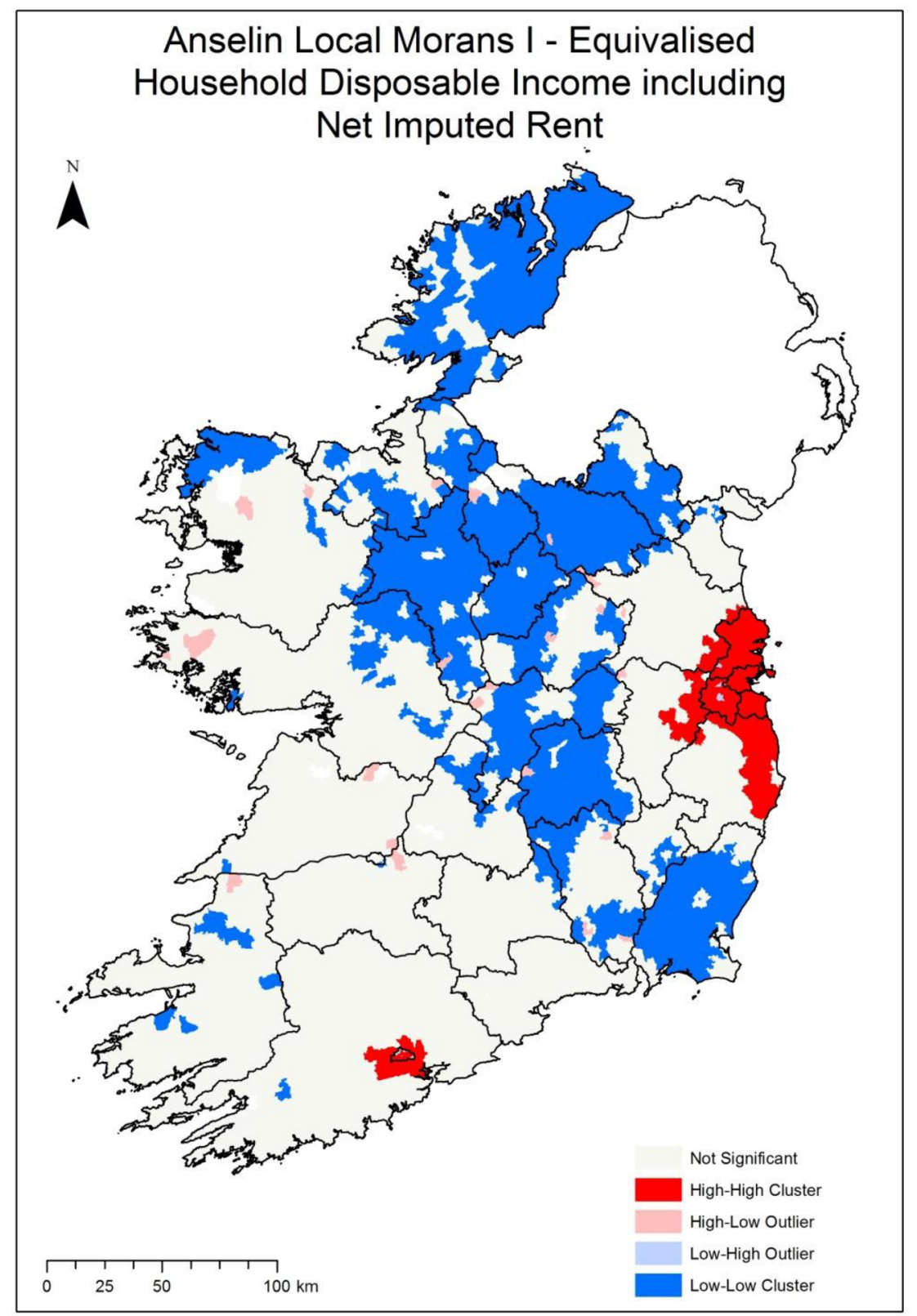

Fig. 7. Anselin Local Moran's I Cluster and outlier analysis of disposable income including net imputed rent.

Table 9

Characteristic of clusters of disposable income including net imputed rent.

\begin{tabular}{lllll}
\hline Median & $H H$ & $H L$ & $L L$ & $L H$ \\
\hline Disposable income & 25,463 & 20,187 & 17,261 & 17,037 \\
Imputed rent & 40,165 & 30,389 & 24,744 & 24,710 \\
Net imputed & 31,200 & 23,739 & 20,566 & 21,945 \\
\% Family & $11.3 \%$ & $15.0 \%$ & $18.9 \%$ & $15.9 \%$ \\
\% Owner Occ & $70.5 \%$ & $74.7 \%$ & $69.6 \%$ & $59.9 \%$ \\
Child depend. & $25.7 \%$ & $31.8 \%$ & $35.3 \%$ & $33.0 \%$ \\
Old age depend. & $20.3 \%$ & $24.7 \%$ & $21.7 \%$ & $13.8 \%$ \\
Tertiary educ. & $38.8 \%$ & $33.0 \%$ & $30.8 \%$ & $19.8 \%$ \\
Employ. rate & $59.8 \%$ & $64.1 \%$ & $58.4 \%$ & $43.4 \%$ \\
Unemp. rate & $11.0 \%$ & $10.9 \%$ & $13.5 \%$ & $20.0 \%$ \\
Work age Shr. & $69.2 \%$ & $64.2 \%$ & $63.9 \%$ & $68.8 \%$ \\
Pop. density & 3,785 & 27 & 71 & 4,982
\end{tabular}

In terms of policy implications, a tax on imputed rent should be examined which may reduce the inequality between those who own a house and those who are renting. The current LPT is attempting to address this however the tax is levied on all properties, this is despite private renters not receiving the same level of benefits from housing as owner-occupiers. The LPT should account for the variation in housing benefits across the life-cycle. Effective implementation may incentivise those in the older age categories to take out a reverse mortgage/annuity. Increased uptake of RMA may result in the older age categories consuming the housing wealth as opposed to bequeathing. This can address issues relating to the inequality of inherited wealth (Atkinson, 1971).

The high rental values particularly in the GDA may hinder an individual's ability to save and eventually draw down a mortgage. Solutions are required to increase an individual's potential to save. There are clear benefits to owner-occupation especially for the elderly. If current trends of decreasing home ownership levels continue, future elderly groups will be particularly vulnerable as they would not have the financial safety net in the form of a housing asset. 


\section{Funding}

This research has been funded through the John and Pat Hume Doctoral Scholarships at Maynooth University, Ireland.

\section{Supplementary materials}

Supplementary material associated with this article can be found, in the online version, at doi:10.1016/j.jhe.2018.11.002.

\section{References}

Alonso, W., 1960. A theory of the urban land market. Pap. Proc. Reg. Sci. Assoc. 6, 149-157.

Alonso, W., 1964. Location and Land Use: Toward a General Theory of Land Rent. Harvard University Press.

Anselin, L., Lozano-Gracia, N., 2008. Errors in variables and spatial effects in hedonic house price models of ambient air quality. Empir. Econ. 34, 5-34.

Atkinson, A.B. 1971. The distribution of wealth and the individual life-cycle. 23, 239-254.

Atkinson, A.B., 1983. The Economics of Inequality. JSTOR.

Bailey, T.C., Gatrell, A.C., 1995. Interactive Spatial Data Analysis. Longman Scientific \& Technical Essex.

Balcazar, C.F., Ceriani, L., Olivieri, S., et al., 2014. Rent imputation for welfare measurement: a review of methodologies and empirical findings. World Bank Poverty Global Pract. Group Policy Res. Work. Paper 7103.

Balcázar, C.F., Ceriani, L., Olivieri, S., et al., 2017. Rent-imputation for welfare measurement: a review of methodologies and empirical findings. Rev. Income Wealth.

Barr, N.A., 1998. The Economics of the Welfare State. Stanford University Press.

Barthold, T.A., 1993. How should we measure distribution. Nation. Tax J. 46, 291-299.

Basu, S., Thibodeau, T.G., 1998. Analysis of spatial autocorrelation in house prices. J. Real Estate Financ. Econ. 17, 61-85.

Bourassa, S.C., Grigsby, W.G. 2000. Income tax concessions for owner-occupied housing.

Brueckner, J.K., 1987. The structure of urban equilibria: a unified treatment of the MuthMills model. Handb. Reg. Urban Econ. 2, 821-845.

Brueckner, J.K., Thisse, J.-F., Zenou, Y., 1999. Why is central Paris rich and Downtown Detroit poor? An amenity-based theory. Eur. Econ. Rev. 43, 91-107.

Brunsdon, C., Comber, L., 2015. An Introduction to R for Spatial Analysis and Mapping. Sage.

Callan, T., Keane, C., 2009. Non-cash benefits and the distribution of economic welfare. Econ. Soc. Rev. 40, 49-71.

Callan, T., Keane, C., Walsh, J.R., 2010. What role for property taxes in Ireland. Econ. Soc. Rev. $41,87$.

Callan, T., O'Donoghue, C., O'Neill, C., 1996. Simulating Welfare and Income Tax Changes (SWITCH) The ESRI Tax-Benefit Model. Economic Social Research Institute, Dublin.

Cocco, J.F., Lopes, P., 2014. Reverse mortgage design. Citeseer.

Costa-Font, J., Gil, J., Mascarilla, O., 2010. Housing wealth and housing decisions in old age: sale and reversion. Hous. Stud. 25, 375-395.

CSO, 2011. National accounts. Available at. http://www.cso.ie/en/census/ census2011smallareapopulationstatisticssaps/.

CSO, 2014. Survey on income and living conditions (SILC) 2012. Available at. http:// www.cso.ie/en/media/csoie/releasespublications/documents/silc/2012/silc_2012. Pdf.

Daly, F., Arnold, T., Burke, J., et al., 2009. Commission on Taxation Report 2009. Stationary Office, Dublin.

Department of Housing Planning and Local Government, 2016. House price statistics. Available at. http://www.housing.gov.ie/housing/statistics/house-prices-loans-andprofile-borrowers/house-price-statistics.

Diggle, P.J., Tawn, J., Moyeed, R., 1998. Model-based geostatistics. J. R. Stat. Soc 47, 299-350.

DoHPLG, 2017. House price statistics. Available at. http://www.housing.gov.ie/ housing/statistics/house-prices-loans-and-profile-borrowers/house-price-statistics.

DSP, 2011. Maximum rent limits 2011. Available at. https://www.welfare.ie/en/Pages/ Maximum-Rent-Limits-by-County.aspx.

Dubin, R.A., Pace, K., Thibodeau, T., 1999. Spatial autoregression techniques for real estate data. J R. Estate Lit. 7, 79-95.

Dubin, R.A., 1992. Spatial autocorrelation and neighborhood quality. Reg. Sci. Urban Econ. 22, 433-452.

ECB, 2016. Key ECB interest rates. Available at. https://www.ecb.europa.eu/stats/ monetary/rates/html/index.en.html.

ESRI, 2018. Cluster and outlier analysis (Anselin Local Moran's I) [Online]. Available. http://pro.arcgis.com/en/pro-app/tool-reference/spatial-statistics/cluster-andoutlier-analysis-anselin-local-moran-s.htm.

Fahey, T., Maître, B., 2004. Home Ownership and Social Inequality in Ireland. Home ownership and social inequality in comparative perspective, pp. 281-303.

Farrell, N., O'Donoghue, C., Morrissey, K., 2010. Spatial microsimulation using quota sampling. Teagasc rural economy research series working paper 7 .

Farrell, N., Morrissey, K., O'Donoghue, C., 2013. Creating a spatial microsimulation model of the Irish local economy. Spat. Microsimulat. 105-125.

Fessler, P., Rehm, M., Tockner, L., 2016. The impact of housing non-cash income on the household income distribution in Austria. Urban Stud. 53, 2849-2866.

Figari, F., Paulus, A., Sutherland, H., et al., 2016. Removing homeownership bias in taxation: the distributional effects of including net imputed rent in taxable income. Fisc. Stud.

Fratantoni, M., 1999. Reverse mortgage choices: a theoretical and empirical analysis of the borrowing decisions of elderly homeowners. J. Hous. Res. 10, 189-208.

Frick, J.R., Goebel, J., Grabka, M. 2007. Assessing the distributional impact of 'imputed rent' and 'non-cash employee income' in microdata: case studies based on EU-SILC (2004) and SOEP (2002). SOEP Paper.

Frick, J.R., Grabka, M.M., 2003. Imputed rent and income inequality: a decomposition analysis for Great Britain, West Germany and the US. Rev. Income Wealth 49, 513-537.

Frick, J.R., Headey, B.W., 2009. Living standards in retirement: accepted international comparisons are misleading. Schmollers Jahrbuch 129, 309-319.

Gkartzios, M., Shucksmith, M., 2015. 'Spatial anarchy'versus 'spatial apartheid': rural housing ironies in Ireland and England. Town Plann. Rev 86, 53-72.

Glaeser, E.L., 2007. The Economics Approach to Cities. National Bureau of Economic Research.

Glaeser, E.L., Gyourko, J. 2005. Urban decline and durable housing. 113, 345-375.

Goldberger, A.S., 1962. Best linear unbiased prediction in the generalized linear regression model. J. Am. Stat. Assoc. 57, 369-375.

Grabka, M.M., Verbist, G., 2015. Non-cash Benefits from Social Housing in Europe: a Comparative Perspective. Herman Deleeck Centre for Social PolicyUniversity of Antwerp.

Hendershott, P.H., White, M., 2000. Taxing and subsidizing housing investment: the rise and fall of housing's favored status. Nation. Bur. Econ. Res.

Hoshino, T., Kuriyama, K., 2010. Measuring the benefits of neighbourhood park amenities: application and comparison of spatial hedonic approaches. Environ. Resour Econ. 45, 429-444.

Hynes, S., Morrissey, K., O'Donoghue, C., Clarke, G., 2009. Building a static farm level spatial microsimulation model for rural development and agricultural policy analysis in Ireland. Int. J. Agric. Resour., Gov. Ecol. 8, 282-299.

Juntto, A., Reijo, M. 2010. Comparability of imputed rent In EU-SILC 2007—difference in variable definitions and methods concerning institutional housing. Methodological paper. Conference in Warsaw.

Kemeny, J., 2002. From Public Housing to the Social Market. Routledge.

Kenna, P., Benjaminsen, L., Busch-Geertsema, V., Nasarre-Aznar, S., 2016. Pilot project-promoting protection of the right to housing-homelessness prevention in the context of evictions. Eur. Commiss VT/2013/056.

Kutty, N.K., 1998. The scope for poverty alleviation among elderly home-owners in the United States through reverse mortgages. Urban Stud. 35, 113-129.

Lyons, R., 2011. Daft.ie House Price Report: 2011 Q2. Available at. https://www.daft.ie/ report/Daft-House-Price-Report-Q2-2011.pdf.

Lyons, R., 2017a. Daft.ie House Price Report: 2017 Q2. Available at. https://www.daft. ie/report/2017-Q2-houseprice-daft-report.pdf.

Lyons, R., 2017b. Daft.ie Irish House Price Report Available at. http://www.daft.ie/ report.

Matsaganis, M., Flevotomou, M., 2007. The Impact of Mortgage Interest Tax Relief in the Netherlands, Sweden, Finland, Italy and Greece. EUROMOD at the Institute for Social and Economic Research.

Mayer, C.J., Simons, K.V., 1994. Reverse mortgages and the liquidity of housing wealth. R. Estate Econ. 22, 235-255.

Meen, G., 2012. Modelling Spatial Housing markets: Theory, Analysis and Policy. Springer Science \& Business Media.

Mills, E.S. 1972. Studies in the structure of the urban economy.

Montero, J.M., Larraz, B., 2010. Estimating housing prices: a proposal with spatially correlated data. Int. Adv. Econ. Res. 16, 39-51.

Morrissey, K., O'Donoghue, C., 2011. The spatial distribution of labour force participation and market earnings at the sub-national level in Ireland. Rev. Econ. Anal. 3, 80-101.

Morrissey, K., O'Donoghue, C., et al., 2013. Validation issues and the spatial pattern of household income. In: O'Donoghue, C., Ballas, D., Clarke, G. (Eds.), Spatial Microsimulation for Rural Policy Analysis. Springer, pp. 87-102.

Moscarola, F.C., D'Addio, A.C., Fornero, E., Rossi, M., 2015. Reverse mortgage: a tool to reduce old age poverty without sacrificing social inclusion. In: Borsch-Supan, A., Weber, G. (Eds.), Ageing in Europe - Supporting Policies for an Inclusive Society. De gruyter.

Muth, R.F. 1969. Cities and housing; the spatial pattern of urban residential land use

Nakajima, M., Telyukova, I. 2014. Reverse mortgage loans: a quantitative analysis.

Norris, M., Winston, N., 2012. Home-ownership, housing regimes and income inequalities in Western Europe. Int. J. Soc. Welfare 21, 127-138.

O'Donoghue, C., 1998. Simulating the Irish tax-transfer system in Eur6. Microsimulat. Unit. MU/RN/26. Dep. Appl. Econ. Univ. Camb.

O'Donoghue, C., Ballas, D., Clarke, G., Hynes, S., Morrissey, K., 2013a. Spatial Microsimulation for Rural Policy Analysis. Springer.

O'Donoghue, C., Morrissey, K., Hayes, P., Loughrey, J., Banks, J., Hynes, S., 2013b. The spatial distribution of household disposable income. In: O'Donoghue, C., Ballas, D., Clarke, G., Hynes, S., Morrissey, K. (Eds.), Spatial Microsimulation for Rural Policy Analysis. Springer.

OECD. 2006. OECD economic surveys: Ireland 2006.

OECD, 2013. OECD Framework for Statistics on the Distribution of Household Income, Consumption and Wealth. OECD Publishing.

OECD, 2014. OECD Available at. http://www.oecd.org/eco/growth/OECD-NoteEquivalenceScales.pdf.

Pace, R.K., Barry, R., Sirmans, C., 1998. Spatial statistics and real estate. J. R. Estate Financ. Econ. 17, 5-13.

Paulus, A., Sutherland, H., Tsakloglou, P., 2010. The distributional impact of in-kind public benefits in European countries. J. Policy Anal. Manag. 29, 243-266.

Pellegrino, S., Piacenza, M., Turati, G. 2011. Assessing the distributional effects of 
housing taxation in Italy: from the actual tax code to imputed rent.

Piketty, T., Goldhammer, A., Ganser, L. 2014. Capital in the twenty-first century.

PRTB, 2011. Private residential tenancies board-rent index. Available at. http://www.

cso.ie/px/pxeirestat/pssn/prtb/homepagefiles/rent_index_statbank.asp.

Rasmussen, D.W., Megbolugbe, I.F., Morgan, B.A., 1997. The reverse mortgage as an asset management tool. Hous. Policy Debate 8, 173-194.

Roback, J., 1982. Wages, rents, and the quality of life. J. Politic. Econ. 1257-1278.

Rosen, S., 1974. Hedonic prices and implicit markets: product differentiation in pure competition. J. Politic. Econ. 82, 34-55.

Rosenthal, S.S., Strange, W.C., 2004. Evidence on the nature and sources of agglomeration economies. Handb. Reg. Urban Econ. 4, 2119-2171.

RTÉ, 2016. Government Set to Alter First-Time Buyer Scheme. RTÉ, Dublin.

Saunders, P., Siminski, P., 2005. Home ownership and inequality: imputed rent and income distribution in Australia. Econ. Papers 24, 346-367.

Shorrocks, A.F., 1975. The age-wealth relationship: a cross-section and cohort analysis. Rev. Econ. Stat. 155-163.

Smeeding, T.M., Weinberg, D.H, 2001. Toward a uniform definition of household income. Rev. Income Wealth 47, 1-24.
Thünen, J.V., 1826. Der isolierte Staat. Beziehung auf Landwirtschaft und Nationalökonomie.

Tobler, W.R., 1970. A computer movie simulating urban growth in the Detroit region. Econ. Geogr. 46, 234-240.

Törmälehto, V-M., Sauli, H., 2013. The distributional impact of imputed rent in EU-SILC 2007-2010. EUROSTAT.

UN, 1977. Provisional guidelines on statistics of the distribution of income, consumption and accumulation of households. Stud. Methods.

UN, 2008. System of National Accounts, 2008. Unit. Nation. Stat. Div.

UN, 2011. Canberra group handbook on household income statistics. Econ. Comm. Eur.

Venti, S.F., Wise, D.A., 1991. Aging and the income value of housing wealth. J. Pub. Econ. 44, 371-397.

Walsh, K., 2013. Property Valuation: Developing, Assessing and Deploying a Valuation Model for Local Property Tax. Revenue Commissioners, Dublin.

Yates, J., 1994. Imputed rent and income distribution. Rev. Income Wealth 40, 43-66.

Watson, D., 2005. Mapping Poverty: national, regional and county patterns. Combat Poverty Agency. 